This item was submitted to Loughborough's Research Repository by the author.

Items in Figshare are protected by copyright, with all rights reserved, unless otherwise indicated.

\title{
SimLean: utilising simulation in the implementation of lean in healthcare
}

PLEASE CITE THE PUBLISHED VERSION

http://dx.doi.org/10.1016/j.ejor.2011.12.029

\section{PUBLISHER}

(c) Elsevier

VERSION

AM (Accepted Manuscript)

LICENCE

CC BY-NC-ND 4.0

REPOSITORY RECORD

Robinson, Stewart, Zoe J. Radnor, Nicola Burgess, and Claire Worthington. 2019. "Simlean: Utilising Simulation in the Implementation of Lean in Healthcare". figshare. https://hdl.handle.net/2134/10205. 
This item was submitted to Loughborough's Institutional Repository (https://dspace.lboro.ac.uk/) by the author and is made available under the following Creative Commons Licence conditions.

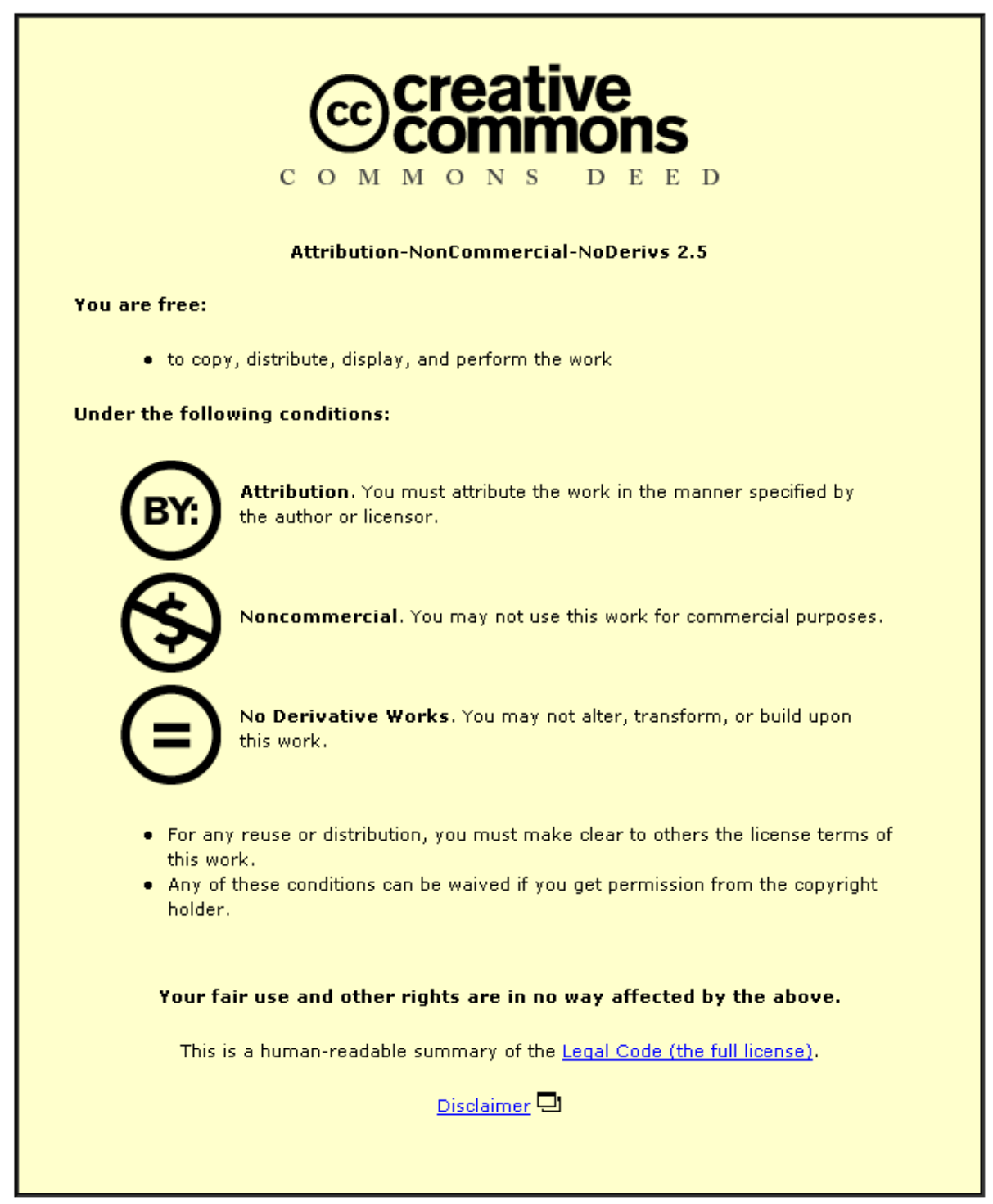

For the full text of this licence, please go to: http://creativecommons.org/licenses/by-nc-nd/2.5/ 


\title{
SimLean: Utilising Simulation in the Implementation of Lean in Healthcare
}

\author{
Stewart Robinson ${ }^{1}$, Zoe J. Radnor ${ }^{2}$, Nicola Burgess ${ }^{1}$, Claire Worthington ${ }^{1}$ \\ ${ }^{1}$ Warwick Business School, University of Warwick, Coventry, CV4 7AL, United Kingdom \\ ${ }^{2}$ Cardiff Business School, Cardiff University, Cardiff, CF10 3EU, United Kingdom
}

\begin{abstract}
Discrete-event simulation (DES) and lean are approaches that have a similar motivation: improvement of processes and service delivery. Both are being used to help improve the delivery of healthcare, but rarely are they used together. This paper explores from a theoretical and an empirical perspective the potential complementary roles of DES and lean in healthcare. The aim is to increase the impact of both approaches in the improvement of healthcare systems. Out of this exploration, the 'SimLean' approach is developed in which three roles for DES with lean are identified: education, facilitation and evaluation. These roles are demonstrated through three examples of DES in action with lean. The work demonstrates how the fusion of DES with lean can improve both stakeholder engagement with DES and the impact of lean.
\end{abstract}

Keywords: Lean, Discrete-Event Simulation, Healthcare, Stakeholder Engagement, Impact

\section{Introduction}

Simulation and lean are approaches that are rarely discussed together, particularly in the healthcare context. This is surprising given that they have a similar motivation: improvement of processes and service delivery. With the current focus on the efficiency of health services there has certainly been a growing interest in both simulation and lean, albeit that this has been largely along completely separate tracks. In this paper we ask how they might work to mutual benefit. In particular, we explore the role of simulation in the implementation of lean in healthcare. The aim is to improve the impact and engagement of both lean and simulation enabling them to work in a symbiotic relationship in improving healthcare systems. In particular, this paper aims to introduce an innovative and novel rapid approach to simulation.

Over the last decade there has been a rapid increase in the implementation of lean in healthcare. In a recent literature review focusing on the use of process improvement methodologies in the public sector $51 \%$ of publications sourced focused on lean, and $35 \%$ of the total specifically focused on lean in health services (Radnor, 2010). Indeed, lean in healthcare appears to have become widespread, especially in the USA, UK and Australia (Brandao de Souza, 2009). Where lean is being implemented tangible benefits have been reported such as reduction of processing or waiting time, increase in quality through a reduction of errors, a reduction in costs (Silvester et al, 2004), alongside intangibles such as increased employee motivation and satisfaction, and increased customer satisfaction (Radnor and Boaden, 2008). Chang et al (2011) show that quality and efficiency can be improved simultaneously in hospitals. However, it is also important to note that many of these 
implementations have been confined to a single process or ward rather than a complete patient pathway which limits the scope of lean to improve healthcare processes (Radnor and Holweg, 2010).

Simulation has a much longer history in healthcare with regular articles on its implementation appearing from the 1970s (Brailsford and Vissers, 2011). Since the early 1990s there has been a huge increase, numbering thousands, in the number of articles being published on simulation in healthcare (Brailsford et al, 2009a). As for manufacturing, simulation promises many benefits for health applications including risk reduction for changes to processes, cost and lead time reduction, increased customer satisfaction and greater understanding of healthcare processes among their stakeholders (Hollocks, 1992). However, these benefits are not necessarily being achieved with much evidence to suggest that simulation is simply not having the impact it could in the health sector (Young et al, 2009).

So the story of lean and simulation in health seems to be one of unrealised potential to improve healthcare delivery. Within the research and this paper we have attempted to cultivate a symbiotic relationship between simulation and lean by creating an approach of 'rapid modelling' within a Lean event. We argue that this has allowed an innovative and novel approach of simulation to be developed whilst also supporting the sustainability of lean. We will first explore the separate roles of lean and simulation in healthcare, outlining their key assumptions and their implementation in the healthcare context. Following this we demonstrate that simulation and lean can be complementary methodologies and describe how the two approaches can be fused through the 'SimLean' approach. We briefly describe three examples of SimLean in action before concluding with an evaluation of the approach and an outline of further work on the development of SimLean.

\section{Lean in Healthcare}

Originating from the Toyota Motor Corporation, lean (also referred to as the Toyota Production System, TPS) is considered to be a radical alternative to the traditional method of mass production and batching principles for optimal efficiency, quality, speed and cost (Holweg, 2007). The history of lean production has been widely discussed, and shall not be recounted here; refer to (Ohno, 1988; Womack et al, 1990; Womack and Jones, 1996; Fujimoto, 1999; Hines et al, 2004; Holweg, 2007) for comprehensive reviews on TPS and lean production. Instead we will define lean in order to focus on the assumptions behind it, and discuss its applications in healthcare.

\subsection{Defining Lean and its Key Assumptions}

Although conceptually simple, it is not easy to define 'lean'. The core to the lean philosophy is to continually improve a process by removing non-value added steps, or 'waste' (Japanese: 'muda'). Taiichi Ohno defined seven wastes for a manufacturing environment (Ohno, 1988); these are shown in column 1 of table 1 . It is not straightforward to transfer these across from high-volume repetitive manufacturing, into low-volume or even service environments. 
Bicheno and Holweg (2009) attempt to translate Ohno's wastes into a service environment and the NHS Institute for Improvement and Innovation (NHSI) (2007) adapted these further by giving examples of healthcare wastes. This translation and the healthcare examples are shown in columns 2 and 3 of table 1 respectively.

Table 1 Ohno’s Original Seven Wastes, Service Wastes, and Healthcare Wastes

\begin{tabular}{|c|c|c|}
\hline $\begin{array}{c}\text { Ohno's Original } \\
\text { Manufacturing Wastes } \\
\text { (Ohno, 1988) }\end{array}$ & $\begin{array}{c}\text { Service Wastes } \\
\text { (Bicheno and Holweg, 2009) }\end{array}$ & $\begin{array}{c}\text { Examples of Healthcare Wastes } \\
\text { (NHSI, 2007) }\end{array}$ \\
\hline $\begin{array}{l}\text { 1. Transportation: } \\
\text { moving products that } \\
\text { are not actually } \\
\text { required to perform } \\
\text { the processing }\end{array}$ & $\begin{array}{l}\text { Delay on the part of } \\
\text { customers waiting for } \\
\text { service, for delivery, in } \\
\text { queues, for response, not } \\
\text { arriving as promised. }\end{array}$ & $\begin{array}{l}\text { Transportation: } \\
\text { - Staff walking to the other end } \\
\text { of a ward to pick up notes } \\
\text { - Central equipment stores for } \\
\text { commonly used items instead } \\
\text { of items located where they } \\
\text { are used }\end{array}$ \\
\hline $\begin{array}{l}\text { 2. Inventory: all } \\
\text { components, work in } \\
\text { process and finished } \\
\text { product not being } \\
\text { processed }\end{array}$ & $\begin{array}{l}\text { Duplication: Having to re- } \\
\text { enter data, repeat details } \\
\text { on forms, copy } \\
\text { information across, } \\
\text { answer queries from } \\
\text { several sources within the } \\
\text { same organisation. }\end{array}$ & $\begin{array}{l}\text { Inventory: } \\
\text { - Excess stock in storerooms } \\
\text { that is not being used } \\
\text { - Patients waiting to be } \\
\text { discharged } \\
\text { - Waiting lists }\end{array}$ \\
\hline $\begin{array}{l}\text { 3. Motion: people or } \\
\text { equipment moving or } \\
\text { walking more than is } \\
\text { required to perform } \\
\text { the processing }\end{array}$ & $\begin{array}{l}\text { Unnecessary Movement: } \\
\text { Queuing several times, } \\
\text { lack of one-stop, poor } \\
\text { ergonomics in the service } \\
\text { encounter. }\end{array}$ & $\begin{array}{l}\text { Motion: } \\
\text { - Unnecessary staff movement } \\
\text { looking for paperwork e.g. } \\
\text { drug sheets not put back in } \\
\text { the correct place, storing } \\
\text { syringes and needles at } \\
\text { opposite ends of the room } \\
\text { - Not having basic equipment } \\
\text { in every examination room }\end{array}$ \\
\hline $\begin{array}{l}\text { 4. Waiting (Delay): } \\
\text { waiting for the next } \\
\text { production step }\end{array}$ & $\begin{array}{l}\text { Unclear Communication and } \\
\text { the wastes of seeking } \\
\text { clarification, confusion } \\
\text { over product or service } \\
\text { use, wasting time finding } \\
\text { a location that may result } \\
\text { in misuse or duplication. }\end{array}$ & $\begin{array}{l}\text { Waiting for: } \\
\text { - Patients, theatre staff, results, } \\
\text { prescriptions and medicines } \\
\text { - Doctors to discharge patients }\end{array}$ \\
\hline $\begin{array}{l}\text { 5. Overproduction: } \\
\text { production ahead of } \\
\text { demand }\end{array}$ & $\begin{array}{l}\text { Incorrect Inventory: Out-of- } \\
\text { stock, unable to get } \\
\text { exactly what was required, }\end{array}$ & $\begin{array}{l}\text { Overproduction: } \\
\text { - Requesting unnecessary tests } \\
\text { from pathology }\end{array}$ \\
\hline
\end{tabular}




\begin{tabular}{|c|c|c|}
\hline & $\begin{array}{l}\text { substitute products or } \\
\text { services. }\end{array}$ & $\begin{array}{l}\text { - Keeping investigation slots } \\
\text { 'just in case' }\end{array}$ \\
\hline $\begin{array}{l}\text { 6. Over- or } \\
\text { inappropriate } \\
\text { processing: resulting } \\
\text { from poor tool or } \\
\text { product design } \\
\text { creating activity }\end{array}$ & $\begin{array}{l}\text { Opportunity Lost to retain or } \\
\text { win customers, failure to } \\
\text { establish rapport, ignoring } \\
\text { customers, unfriendliness, } \\
\text { and rudeness. }\end{array}$ & $\begin{array}{l}\text { Over processing: } \\
\text { - Duplication of information } \\
\text { e.g. asking for patients' } \\
\text { details several times } \\
\text { - } \text { Repeated clerking of patients }\end{array}$ \\
\hline $\begin{array}{l}\text { 7. Defects: the effort } \\
\text { involved in inspecting } \\
\text { for and fixing defects }\end{array}$ & $\begin{array}{l}\text { Errors in the service } \\
\text { transaction, product } \\
\text { defects in the product- } \\
\text { service bundle, lost or } \\
\text { damaged goods. }\end{array}$ & $\begin{array}{l}\text { Correction: } \\
\text { - Readmission because of failed } \\
\text { discharge or adverse drug } \\
\text { reactions } \\
\text { - Repeating tests because } \\
\text { correct information was not } \\
\text { provided }\end{array}$ \\
\hline
\end{tabular}

Womack and Jones (1996) define lean and its implementation through 5 principles which are based on the assumption that organisations are made up of processes. These principles, outlined in table 2, link the concepts of value, waste reduction and continuous improvement (kaizen) into an ever-repeating process.

Table 2 The Five Lean Principles (Womack and Jones, 1996)

1. Specify the value desired by the customer.

2. Identify the value stream for each product/ service providing that value and, challenge all of the wasted steps.

3. Make the product flow continuously. Standardise processes around best practice allowing them to run more smoothly, freeing up time for creativity and innovation.

4. Introduce 'pull' between all steps where continuous flow is impossible. Focus upon the demand from the customer and trigger events backwards through the value chain.

5. Manage towards perfection so that non-value adding activity will be removed from the value chain so that the number of steps, amount of time and information needed to serve the customer continually falls.

This focus on waste alone, however, rather restricts the scope of lean. Originally, muda was one of three concepts: muda, mura and muri (Hines et al, 2008). Mura relates to 'unevenness', and argues for stable demand that enables smooth process flows. The more uneven demand, the more variation in the process, and the less efficient the process will be. Muri is the term for 'excessive strain', which argues for good working conditions that prevent injuries and strain on the worker which is a clear factor in reducing absenteeism.

There is a general perception that lean is only concerned with waste reduction and subsequent cost reduction. This is simply not true, and in fact marks a severe limitation of the common 
understanding of lean. As Hines et al (2004) note, there are in fact two ways to increase customer value: by reducing waste and thus the cost of a product or service; or by increasing the value-adding activities without increasing the cost of the service or product.

Putting all these elements together, lean can be defined as 'a management practice based on the philosophy of continuously improving processes by either increasing customer value or reducing non-value adding activities (Muda), process variation (Mura), and poor work conditions (Muri).' (Radnor and Holweg, 2010)

\subsection{The Implementation of Lean in Healthcare}

As outlined in table 1, the implementation of lean in a healthcare setting, particularly a hospital, should remove duplicate processes and unnecessary procedures such as: recording patient details in multiple formats and places; patients being moved to wards before beds are available; patients being moved from one ward to another; excessive waiting for doctors and consultants; and uncoordinated, variable discharge processes resulting in a longer length of stay than necessary (NHSI, 2007).

Evidence presented through the literature indicates that lean has been embraced across public services, including healthcare, especially since 2005 (Radnor, 2010). Brandao de Souza (2009) gives a historical perspective on the implementation of lean into healthcare suggesting that the use of lean in the UK first appeared in 2001 and, in the USA in 2002. Since then the number of academic articles has risen with 'over 90 publications found in ten countries from 2002 onwards referring to the use of lean in healthcare' (Brandao de Souza, 2009, p.122).

Table 3 illustrates some examples of the implementation of lean in health and the methodology adopted. The third column lists the benefits of the lean implementation with tangible benefits focusing on a reduction in time, space and cost. The resulting improvements in quality and dependability will impact on both efficiency and effectiveness. Intangible benefits include a better understanding of patients, cross-team synergies, and a rise in employee motivation and morale.

Table 3 Examples of Lean Implementation in Healthcare (Wysocki, 2004; Guthrie, 2006; Radnor et al, 2006)

\begin{tabular}{|l|l|l|}
\hline \multicolumn{1}{|c|}{ Organisation } & \multicolumn{1}{|c|}{ Methodology } & \multicolumn{1}{c|}{ Impact } \\
\hline $\begin{array}{l}\text { Scotland Cancer } \\
\text { Treatment }\end{array}$ & Lean & $\begin{array}{l}\text { Patient waiting times to first appointment } \\
\text { reduced from an average 23 to 12 days and } \\
\text { improvement of patient flow time for patients of } \\
48 \%\end{array}$ \\
\hline $\begin{array}{l}\text { Royal Bolton } \\
\text { Hospital }\end{array}$ & $\begin{array}{l}\text { Bolton Improving } \\
\text { Care Systems } \\
\text { (Lean) }\end{array}$ & $\begin{array}{l}\text { Direct savings of } £ 3.1 \mathrm{~m} \\
\text { Death rate for patients fell by a third. } \\
\text { The time taken to process important categories }\end{array}$ \\
\hline
\end{tabular}




\begin{tabular}{|l|l|l|}
\hline $\begin{array}{l}\text { Nebraska Medical } \\
\text { Centre }\end{array}$ & $\begin{array}{l}\text { Lean principles to } \\
\text { redesign the work } \\
\text { area in the sterile } \\
\text { processing centre } \\
\text { and in the clinical } \\
\text { laboratories }\end{array}$ & $\begin{array}{l}\text { Reduced staff walking by 167 miles a year. } \\
\text { Reduce lab space by } 825 \text { sq ft and specimen } \\
\text { processing turnaround time by 20\% } \\
\text { Reduced manpower by 11 Full Time } \\
\text { Equivalents (FTEs), who were redirected to } \\
\text { other critical work. } \\
\text { Average length of stay decreased from } 6.29 \\
\text { days to 5.72 days. }\end{array}$ \\
\hline UK Hospital & $\begin{array}{l}\text { Application of lean } \\
\text { principles and } \\
\text { techniques from GP } \\
\text { to hospital } \\
\text { appointment }\end{array}$ & $\begin{array}{l}\text { Implementation of an intranet based waiting } \\
\text { list module brought about greatly reduced } \\
\text { waiting times. }\end{array}$ \\
\hline $\begin{array}{l}\text { The Pittsburgh } \\
\text { General Hospital }\end{array}$ & Lean techniques & $\begin{array}{l}\text { Change to the procedure for intravenous line } \\
\text { insertion giving a 90\% drop in the number of } \\
\text { infections after just 90 days. The new } \\
\text { procedures saved almost \$500,000 a year in } \\
\text { intensive-care-unit costs. }\end{array}$ \\
\hline
\end{tabular}

In terms of lean activities, we can distinguish between three groups of tools: assessment, improvement, and performance monitoring. Assessment tools, such as process mapping, are used to review the performance of existing organisational processes in terms of their waste, flow or capacity to add value. Improvement tools are used to support and improve processes. For instance, Rapid Improvement Events (RIEs), which are held over 3 to 5 days, involve staff evaluating, developing and redesigning processes through problem solving or housekeeping tools such as 5S (sorting, setting in order, sweeping, standardising and sustaining). Finally, monitoring tools are used to measure and monitor the processes and their improvement. These include visual management which promotes the use of visible information via performance boards to manage the work. There is evidence to show that these tools are in use in hospitals and that they are improving emergency care services, intensive care units and operating units, and reducing waiting times (Silvester et al., 2004).

Although lean is increasingly prevalent in healthcare, there is little evidence of a full implementation of lean to the level achieved by Toyota (Spear, 2005). Indeed, the literature suggests that healthcare organisations are implementing lean by using simple tools and techniques on small enclosed projects which are creating 'pockets of best practice' (Brandao de Souza, 2009; Radnor and Holweg, 2010). Royal Bolton NHS Foundation Trust is cited as the closest to a complete application of lean in the UK (Radnor, 2010).

These findings are mirrored by those from our own study. Radnor et al (2009) analysed the annual reports 2007/08 of 152 acute hospital trusts in England for evidence of lean led improvement activity. In the sample, 80 (53\%) hospital trusts cite the application of lean 
principles. The extent of lean implementation was found to vary considerably between hospital trusts. This ranged from those that cited the use of tools such as process mapping and 5S, to those that specified a few ad hoc projects, to those with a clearly defined programme of service improvement based around lean methodology. Only five hospital trusts attested to the adoption of lean principles as part of the culture of the organisation, aligning strategy with operational objectives and developing a philosophy of work based around continuous improvement and lean. The most frequent category of approach to lean implementation, however, was identified as a 'few projects', thus supporting the picture projected from the extant literature that many hospital trusts currently implementing lean are doing small projects that do not form part of an integrated approach to service improvement (Spear, 2005; Young and McClean, 2008; Brandao de Souza, 2009; Radnor and Holweg, 2010).

\section{Simulation in Healthcare}

In a similar fashion to lean, discrete-event simulation (DES), which is the simulation approach that this paper focuses on, emerged from manufacturing. The first DES language was developed by K.D. Tocher for the United Steel Corporation in the late 1950s (Tocher and Owen, 2008). Useful histories of the development of DES can be found in Nance and Sargent (2002), Robinson (2005) and Hollocks (2006, 2008). Here we will focus on the definition of and assumptions behind DES, and discuss its applications in healthcare.

\subsection{Defining DES and its Key Assumptions}

Banks et al (2005, p. 3) define simulation as 'the imitation of the operation of a real-world process or system over time.' DES is a specific approach to simulating processes and systems in which the state of a system changes instantaneously at points in time, for instance, a customer arrives or a service activity is completed. This approach is particularly suited to modelling queuing systems (Pidd, 2004). Of course, many healthcare processes can be conceived as queuing systems in which it is primarily patients who wait.

Robinson (2004) discusses the key reason for using DES as the need to model processes that are subject to variability and that are interconnected, which leads to complexity. Variability can be thought of in terms of predictable variability (e.g. shift changeovers) and unpredictable variability (e.g. patient arrival patterns and consultation times). Given that most processes are subject to a range of sources of variability, which are interconnected (e.g. arrival profiles, to triage time, to initial consultation time, etc.), the process becomes complex. As a result, the performance of the process is difficult to predict; hence the need for simulation. Complexity arises not just from the scale of the process under investigation, but also through the dynamic interaction and feedback between elements of the process. Meanwhile, queues emerge between process steps as a result of the complex interaction of individual processes which are subject to variability. Hence the key assumptions of DES are that processes are subject to variability, they are interconnected and complex; queues emerge 
within the process and process performance (process flow) is difficult, or indeed impossible, to predict without a simulation.

DES is primarily used as a means for testing whether a proposed process performs as expected and to look for means of improving a process. According to Hollocks (1992) the common benefits of using DES in a manufacturing context are risk reduction, greater understanding, operating cost reduction, lead time reduction, faster plant changes, capital cost reduction and improved customer service. These benefits can easily be translated to other contexts such as services and healthcare. The actual implementation of DES in healthcare may not be so straightforward with authors positing a range of reasons why implementing DES in healthcare is more problematic than in other domains (Brailsford, 2005; Kuljis et al, 2007; Eldabi, 2009; Young et al, 2009). Two key differences that are stated in relation to the stakeholders are: the difficulty of engaging them in DES studies, and the problem of managing the conflicting interests of multiple stakeholders (Brailsford et al, 2009b; Eldabi, 2009).

\subsection{The Implementation of DES in Healthcare}

DES then, provides a means for improving healthcare processes by enabling options to be tested and experimented with before making costly investments. As a result, it helps reduce wasted resources and identify unforeseen impacts of change (NHSI, 2010a).

The history of DES for healthcare applications goes back as early as the 1960s (Pitt, 2008) with regular articles being published from the 1970s (Brailsford et al, 2009a). Today, there is a huge interest in the academic literature in the use of DES to help improve healthcare provision. Brailsford et al (2009a) claim to have found over 176,000 articles on modelling and simulation in healthcare, of which a quarter they estimate are on simulation. Over $80 \%$ of these articles have appeared since the 1990s. Indeed, there seems to be an increasing growth in papers on modelling in healthcare. Brailsford et al estimate that currently the number of articles is expanding at a rate of 30 per day.

Within this literature there are many examples of DES being applied across a wide range of healthcare activities and issues. Here we provide some examples for illustrative purposes. Cook County Hospital in Chicago investigated the spread and containment of hospitalacquired infections using a DES model (Hagtvedt et al, 2009). Through the model the benefits of hand hygiene and isolation policies were identified. Aaby et al (2006) describe how Montgomery County's Public Health Service (Maryland) uses DES to help plan for disease outbreaks such as pandemic flu or from bioterrorism attacks. The model helps identify staff resources and to design clinics to reduce congestion for dispensing vaccines to the community. North Mersey Community National Health Service Trust in the UK used DES to improve walk-in health centres by smoothing demand (using mixed walk-in and scheduled appointments) and investigating staffing requirements (Aston et al, 2005). University Hospital Wales investigated the bed requirements in a critical care unit using a DES model in order to minimise the cancellation of elective surgery while maintaining a 
reasonable level of bed-occupancy (Griffiths et al, 2010). Katsaliaki and Brailsford (2007) discuss the modelling of ordering policies in the blood supply chain. The aim of the model is to reduce shortages and waste, improve service levels and safety, and reduce cost.

Where DES is being applied a significant focus is on operational models, especially of emergency departments (Pitt, 2008). Indeed, Paul et al (2010) found 43 simulation studies of emergency departments in the literature. Outside of this, reviews of simulation in healthcare show a wide range of other applications such as: planning, scheduling, reorganisation and management of healthcare and hospital services, communicable diseases, bio-terrorism, screening, costs of illness, economic evaluation (comparing alternative healthcare interventions), policy and strategy evaluation (Fone et al, 2003; Mustafee et al, 2010) and performance modelling (Günal and Pidd, 2010). Jacobson et al (2006) provide a comprehensive review of healthcare applications for DES under two headings: patient flow and healthcare asset allocation. Meanwhile, Jun et al (1999) specifically focus on DES applications in healthcare clinics, identifying applications in the following areas from a review of the literature: patient scheduling and admissions, patient routing and flow schemes, scheduling and availability of resources, and allocation of resources (bed sizing and planning, room sizing and planning, staff sizing and planning). Eldabi et al (2007) suggest a future focus for simulation in healthcare should be on whole system modelling; something that is demonstrated through a simplified simulation model of a whole hospital by Günal and Pidd (2011).

Despite the burgeoning literature on healthcare simulation and some success stories, it appears that in practice simulation is having much less impact on healthcare than it does in other sectors, particularly manufacturing and defence (Young et al, 2009). Much of the work is led by academic groups for research purposes and this is having only limited impact on healthcare practice. Our own research also highlights the limited use of simulation by healthcare trusts. From a search of the 2007/08 annual reports of 152 acute general hospital trusts in the UK, only seven are identified as using modelling and simulation.

\section{A Fusion of DES and Lean}

There is only limited evidence of simulation and lean being used together; see, for instance, Jahangirian et al. (2010). Simulations which are played out manually to demonstrate lean principles for training purposes are not uncommon. For a useful review see Badurdeen et al (2010). In some cases these are even computerised (e.g. Ncube, 2010), but such 'games' are not full DES models and they do not represent the participants' real system.

A prime use for DES has been for creating a dynamic process, or value stream, map. In this case DES is typically used to model the as-is and the to-be processes; the simulation effectively acting as an enhanced map (Dennis et al. 2000; Abdulmalek and Rajgopal, 2006; Marvel and Standridge, 2009; Anand and Kodali, 2009; Solding and Gullander, 2009). Reijersa and Liman Mansar (2005) identify simulation as a useful tool within a wider business process redesign framework. Meanwhile, Fredendall et al. (2010) use simulation to 
study work load control rules, seeing such methods for reducing work-in-progress as an essential element of a lean approach. There are also examples of DES being used for more general learning about lean principles. Shannon et al (2010) describe a DES model that enables the user to explore the impact of alternative lean strategies such as batch size, workstation processing time, rework time and WIP storage capacity on a hypothetical production system. Detty and Yingling (2000) describe a DES model of a real assembly system with and without lean principles implemented as a means for understanding the benefits of lean.

In a healthcare context, Young et al (2004) see DES as a means for determining the benefits of lean (and other process improvement methodologies) before implementation. Khurma et al (2008) provide a specific example of using DES to investigate the impact of lean improvements in an emergency department. Otherwise, much of the lean specific work focuses on teaching lean principles either through manual or computer-based games, but not specifically with DES (e.g. see NHSI, 2010b). Although they do not specifically discuss DES and lean, Proudlove et al (2007) demonstrate how the use of simple models can be effective in giving generic insights into improving patient flow.

\subsection{DES and Lean: Complementary Methodologies}

The discussion above demonstrates that DES and lean are largely adopted in isolation to one another. This is despite them having a similar motivation, that is, improvement of processes and service delivery. We can investigate the complementarity of DES and lean from a theoretical perspective by considering how the key assumptions of DES fit the three key concepts of lean: muda, mura and muri.

DES and Muda. Table 4 sets out how the key assumptions of DES (in italics) match the lean concept of muda (reducing waste) as defined by Ohno. This is achieved by identifying the role of DES in helping to reduce each of the seven wastes defined by Ohno.

Table 4 The Role of DES in Reducing Waste (Muda)

\begin{tabular}{|c|l|}
\hline \multicolumn{1}{|c|}{ Ohno's Original Wastes } & \multicolumn{1}{|c|}{ Role of DES } \\
\hline $\begin{array}{l}\text { 1. Transportation: moving products } \\
\text { that are not actually required to } \\
\text { perform the processing }\end{array}$ & $\begin{array}{l}\text { Modelling the process flow and measuring } \\
\text { transportation times }\end{array}$ \\
\hline $\begin{array}{l}\text { 2. Inventory: all components, work in } \\
\text { process and finished product not } \\
\text { being processed }\end{array}$ & Modelling queues (inventory) \\
\hline $\begin{array}{l}\text { 3. } \text { Motion: people or equipment } \\
\text { moving or walking more than is } \\
\text { required to perform the processing }\end{array}$ & $\begin{array}{l}\text { Modelling the interconnection between resources } \\
\text { (people and equipment) and the process }\end{array}$ \\
\hline 4. Waiting (Delay): waiting for the & Modelling queues that evolve as a result of \\
\hline
\end{tabular}




\begin{tabular}{|l|l|}
\hline \multicolumn{1}{|c|}{ next production step } & variability in interconnected processes \\
\hline $\begin{array}{l}\text { 5. Overproduction: production ahead } \\
\text { of demand }\end{array}$ & $\begin{array}{l}\text { Modelling the interconnection between variability } \\
\text { in demand and variability in production }\end{array}$ \\
\hline $\begin{array}{l}\text { 6. Over- } \text { or inappropriate processing: } \\
\text { resulting from poor tool or product } \\
\text { design creating activity }\end{array}$ & $\begin{array}{l}\text { Modelling the process flow and measuring } \\
\text { utilisation of resources and processes }\end{array}$ \\
\hline $\begin{array}{l}\text { 7. Defects: the effort involved in } \\
\text { inspecting for and fixing defects }\end{array}$ & $\begin{array}{l}\text { Modelling of variability in defect incidence and } \\
\text { detection, and its impact (interconnection) on the } \\
\text { process flow }\end{array}$ \\
\hline
\end{tabular}

DES and Mura. The need to model variability is a key assumption of DES since this is a major source of process inefficiency. Similarly, mura argues that unevenness in demand (which is a key source of process variability) leads to process inefficiency.

DES and Muri. DES models of the process flow enable the utilisation of resources, including workers and staff, to be determined and bottlenecks to be identified. Understanding how workers are being utilised also provides insights into their wellbeing and safety. In a similar fashion, muri focuses on reducing the strain on workers and staff.

Given the similarity in motivation between DES and lean, and the correspondence between their concepts and underlying assumptions, we argue and have illustrated theoretically that DES and lean are indeed complementary methodologies.

\subsection{The Complementarity of DES and Lean: An Empirical Perspective}

We have obtained further evidence for complementarity of DES and lean through interviews with a cross section of employees in two UK hospital trusts (table 5): one in the north west of England and the other in the midlands region. A total of 36 interviews took place in two trusts with senior executive managers, senior medical consultants, departmental managers, nurses, support workers, ward clerks and staff trained in lean facilitation. All interviews were conducted using an identical semi-structured format allowing them all to be consistently rich in depth and detail. The structure sought to solicit data relating to the context of service improvement, the perceptions and understanding of what lean is and how lean was being implemented in the trust. As part of the interview process the interviewees were introduced to the concept of computer based simulation through a simple screenshot of a model and an explanation of the idea of DES. They were then asked about their enthusiasm for using DES and about their perception of the potential for its use alongside lean.

Table 5 Key Characteristics of the Case Study Hospital Trusts

\begin{tabular}{|l|c|c|}
\hline & Hospital A & Hospital Z \\
\hline Location & Midlands region of England & North west England \\
\hline Number of employees & 6,500 & 3,600 \\
\hline
\end{tabular}




\begin{tabular}{|l|c|c|}
\hline $\begin{array}{c}\text { Local catchment population } \\
\text { (approx.) }\end{array}$ & 500,000 & 320,000 \\
\hline Number of interviews & 24 & 12 \\
\hline $\begin{array}{l}\text { Method of lean } \\
\text { implementation }\end{array}$ & $\begin{array}{c}\text { Programme of 18 projects } \\
\text { across two years } \\
\text { Internal change team }\end{array}$ & $\begin{array}{c}\text { Systemic: an 'Improving } \\
\text { Care System' }\end{array}$ \\
\hline
\end{tabular}

All the interviews were recorded and transcribed verbatim and analysed using NVivo 8 (2010). Individual case reports were generated based around the emergent themes of the transcripts. The report was then presented to each trust's senior executives for validation.

All the respondents were supportive of the use of DES alongside lean. When they were asked how they thought DES might be used alongside lean, perceptions generally fell into two categories of use: 'an interactive and dynamic process map' bringing the process map to life; and a 'what-if' scenario tool for experimenting with process configurations and testing proposed changes.

The most frequently cited use for DES with lean was in the form of an electronic value stream map. The benefits of such were described as a 'dynamic' visualisation of the process that can be used interactively with the added benefit of being able to demonstrate the value stream mapping (VSM) exercise to people who were not in attendance when the VSM was created. One lean leader recalled an example where a second RIE was needed to implement a change since the participants failed to buy-in to an improvement idea the first time around. This respondent felt that the model may have avoided the need for the second RIE as the proposed change could have been simulated using the model. Others, particularly medical consultants, were attracted to the visual aspect of a DES model. Meanwhile, some medical consultants expressed their dislike of process maps drawn on brown paper and post-it notes (a typical feature of lean led improvement activity), adding 'a computer simulation using real data would provide you with a dynamic process map and I have to say a dynamic process map would give me more of an understanding of a process than someone putting yellow and green post-its on a brown bit of paper on a wall.’

Although not a computer-based or a DES model, many respondents spoke favourably about simulated games in which they learnt about lean principles. These were typically delivered through Lego-brick games of manufacturing processes. Their aim is to provide key lessons in reducing waste and improving flow.

\section{SimLean: Using DES with Lean in Healthcare}

So, given that there is a clear complementarity of DES and lean and also a positive interest in using DES with lean in a healthcare context, how can DES be used as part of a lean initiative in a healthcare organisation? Based on our understanding of DES and lean, and the responses from the interviews in the hospital trusts, we are able to identify three key roles for DES with lean (figure 1): educate, engage/facilitate and experiment/evaluate. These roles roughly equate to activities that would happen before, during and after a lean event such as an RIE. We describe this approach for integrating DES and lean in healthcare as 'SimLean' and the 
three roles are denoted as SimLean Educate, SimLean Facilitate and SimLean Evaluate respectively.

Figure 1 SimLean: The Roles of DES with Lean in Healthcare

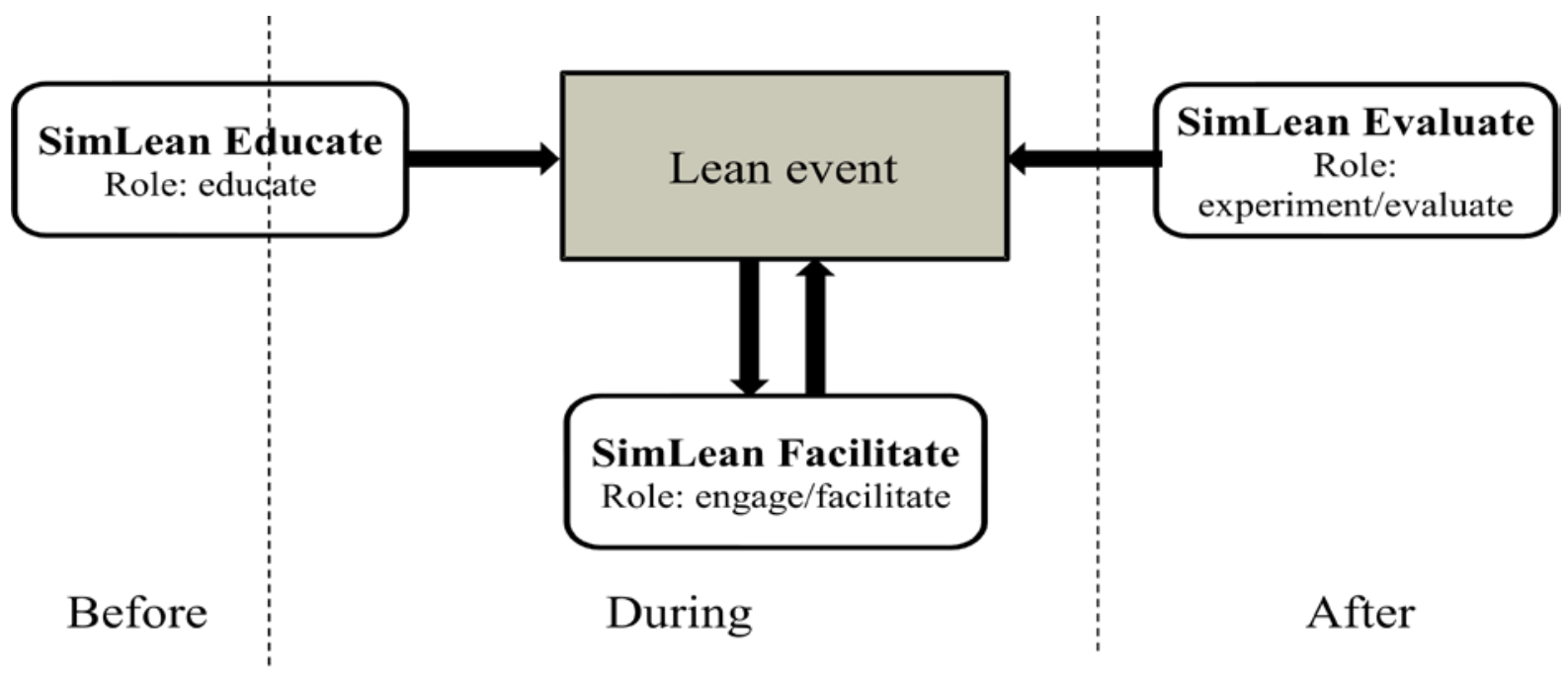

SimLean Educate. DES can play an educational role in teaching key lean principles. It provides a powerful means for demonstrating and understanding the dynamics of healthcare processes. This enables key lessons to be learnt in terms of reducing waste (muda), unevenness (mura) and excessive strain (muri). DES also provides an environment in which ideas can be tried out rapidly, giving much faster turnaround than can be achieved through manual simulation exercises such as Lego-brick games. The idea is to have one or more prebuilt standard DES models that can be used for delivering key lean lessons. These models could be used as part of general lean training (before a lean event starts) or during a lean event, at the start and/or part way into the event if a specific lesson would prove useful at this point (e.g. for myth busting).

SimLean Facilitate. Most lean events that concentrate on process flow involve the drawing of a process map. There is a clear interest in using DES to create a dynamic version of this map. This could be achieved during an event through the rapid development of a simple process map DES model which could then be used to better understand the dynamics of the as-is process, engaging the participants, and to facilitate the exploration of alternative ideas for the to-be process during the event.

SimLean Evaluate. This involves the development of detailed DES models of to-be processes which would be used to experiment with alternative options and to evaluate their effectiveness. This is very much a traditional use of DES which typically requires days to weeks of modelling, detailed data, thorough model validation and statistically sound experimentation. By its very nature this would have to take place after a lean event as a 
means for testing the ideas generated from the event and creating new suggestions where necessary. Such models could also be used in the longer-term to aid implementation and as the basis for continuous improvement.

We now provide brief examples of SimLean Educate, SimLean Facilitate and SimLean Evaluate.

\subsection{Example of SimLean Educate}

Figure 2 shows an example of a SimLean Educate model that we have used with University Hospitals Coventry and Warwickshire NHS Trust at the beginning of a one day workshop to improve theatre processes. It shows patients arriving, initially as a batch at the beginning of a theatre session, and going to a holding bay where they are prepared for theatre. Following their operation the patients wait in a recovery area and then they are either discharged or admitted to a ward. The model generates results on the utilisation of resources, size of queues and the number of patients in the system (including arrivals and discharges).

Figure 2 Example SimLean Educate DES Model: Theatres Process

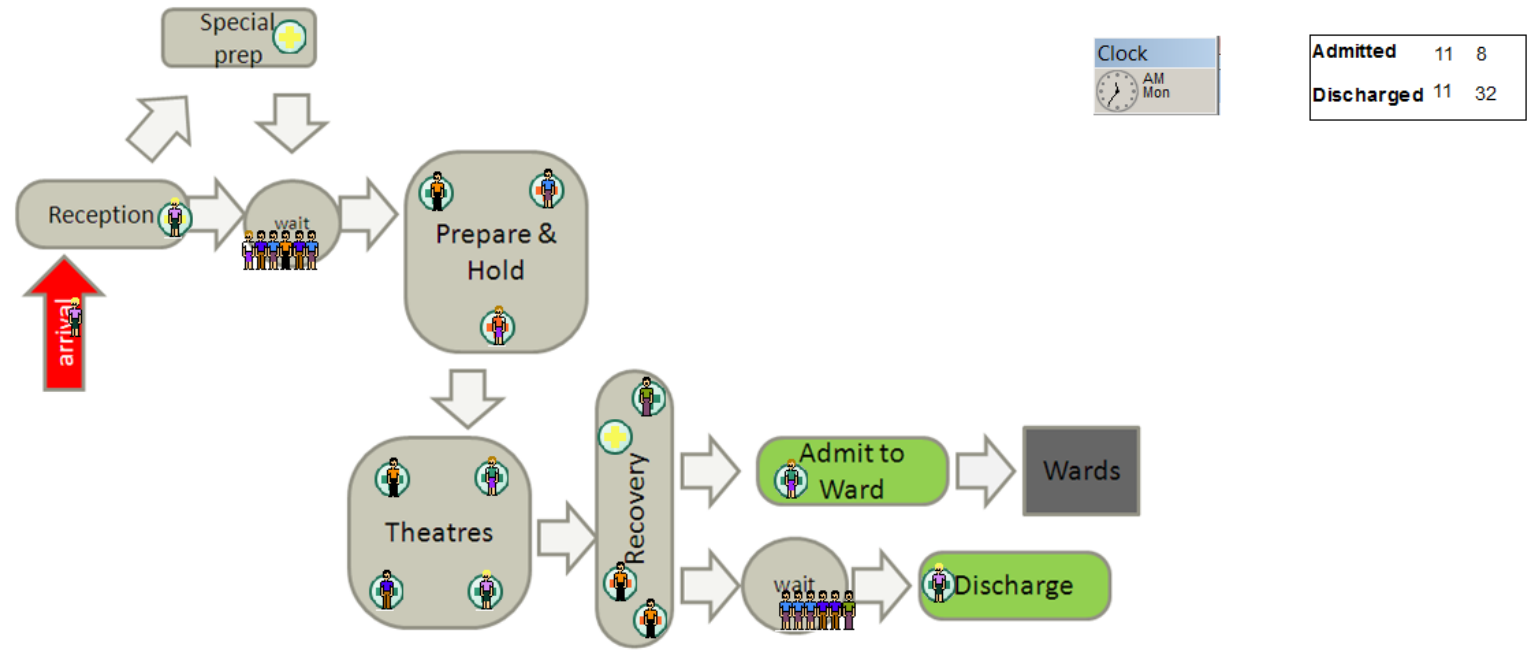

This model is based on a standard SimLean Educate model which was calibrated through a pre-event meeting with the lean team at the trust. The aim of the calibration meeting is not to develop an exact representation of the real process, but to set process names and the model data (quantities of resources and timings) to approximately the right level. In this way the workshop participants are able to identify with the process represented in the model. We have been able to use this same model for an outpatients event simply by changing process names and data, and with some minor changes to the process represented. As such, the model shown in figure 2 can quickly be adapted for many different healthcare contexts.

As part of an improvement workshop the model is presented in a 30 to 45 minute session through a Powerpoint presentation that outlines the purpose of the session, the nature of the 
model and the results that the model generates. The participants are then taken through two or three lean lessons which are demonstrated by running the model and summarising the relevant results. Typical lessons that we have demonstrated using this model are the effects of: batching patients, prioritisation of patients, safeguarding resources for specific activities and changes in resource utilisation.

\subsection{Example of SimLean Facilitate}

We participated in a one week RIE at Royal Bolton Hospital NHS Foundation Trust that looked at the paediatric observation and assessment unit (Worthington et al, 2010). The workshop, which was led by the Bolton Improving Care System (BICS) team (the Trust's lean transformation team), involved managerial, nursing and clinical staff, including consultants. On the first day of the workshop the participants generated the process map shown in figure 3 which was then converted into a dynamic process map (figure 4) using the SIMUL8 DES software (SIMUL8, 2010) in time for the second day of the workshop. As the model ran it provided a dynamic visual display of the process and it generated results on queue sizes, resource utilisation and the number of patients in the system. The simulation was demonstrated during the second day of the workshop and used to explore some alternative process designs. The model showed that triaging while the patient was in a bed did not create a major problem; as a result, it was decided to trial this idea. The model also showed that it was important for a doctor to visit the unit in the afternoon so that any discharges can be made before the evening rush.

Figure 3 Process Map for Bolton Paediatric Observation and Assessment Unit (Worthington et al, 2010)

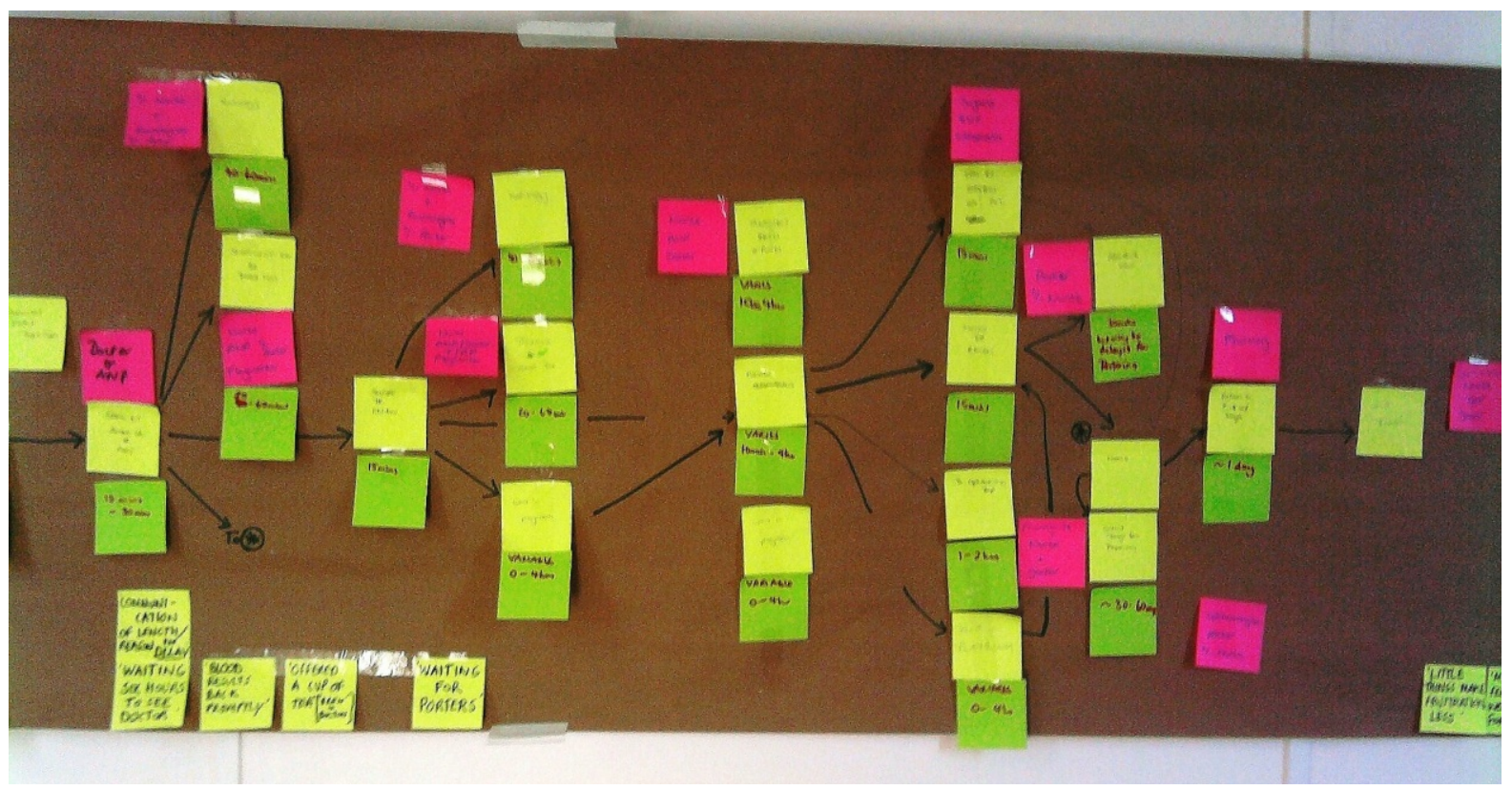

Figure 4 SIMUL8 DES Model of the Bolton Process Map 


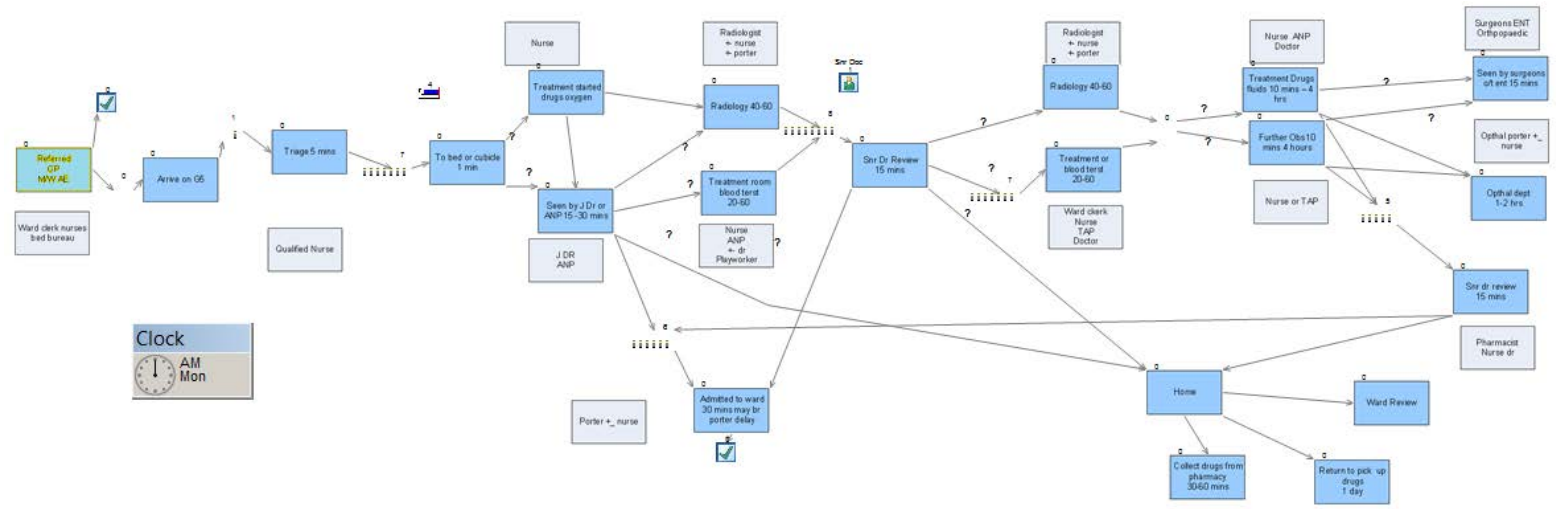

Generating a dynamic process map so rapidly requires tools that enable rapid modelling, a simplified model and access to the required data. DES tools such as SIMUL8 enable basic constructs such as activities, queues, arrivals and routing to be assembled quickly. However, it is important to restrict the detail that is modelled to a simple level. This not only facilitates rapid modelling, but it also has the advantage of limiting the data requirements (Robinson, 2008). Indeed, we only ask for approximate data on patient arrivals, process timings (minimum, mode and maximum) and routing from one process to another (based on percentages or type of patient). These are the sort of data that can be either estimated or collected as part of the workshop, giving even greater engagement with and ownership of the model by the workshop participants. As a result of the model simplifications, the dynamic process map has relatively low fidelity, but it does provide information and an understanding of the process beyond that of a static process map. To create a higher fidelity model would require a greater level of detail and more accurate data. This can be achieved through SimLean Evaluate, which might use the SimLean Facilitate model as a basis for developing a more detailed model.

\subsection{Example of SimLean Evaluate}

We developed a detailed simulation of a cystic fibrosis (CF) clinic for the Heart of England NHS Foundation Trust in Birmingham. The CF clinic has over 300 patients from a wide geographical area who make regular visits. The facility has eight treatment rooms with patients needing to go through a series of treatment stages on each visit. Given the danger of cross infections, it is important to reduce to a minimum the time that patients spend in the communal waiting area.

Based on a map of the CF clinic process the simulation model shown in figure 5 was created. Albeit a relatively small model, it did contain detailed information on patient arrivals, times in treatment rooms, the complex paths possible through the process, the allocation of work to the medical staff and the flow of patient notes. Following model validation with the CF team, model runs were used as a catalyst for discussion around issues such as the impact of did-notattends, the ordering of activities and the bottlenecks caused by the length of the clinicians' consultation times. This enabled the team to generate ways of improving the process, for example, they identified that it is important for a doctor to see the patient first and then for a 
nurse to follow immediately after. This is because of the high variability in nurse consultation times. It was decided to improve communication by putting hangers on the consultation room doors to show which member of staff is with a patient. The model also demonstrated that one spirologist is insufficient.

Figure 5 SIMUL8 DES Model of the Heart of England CF Clinic
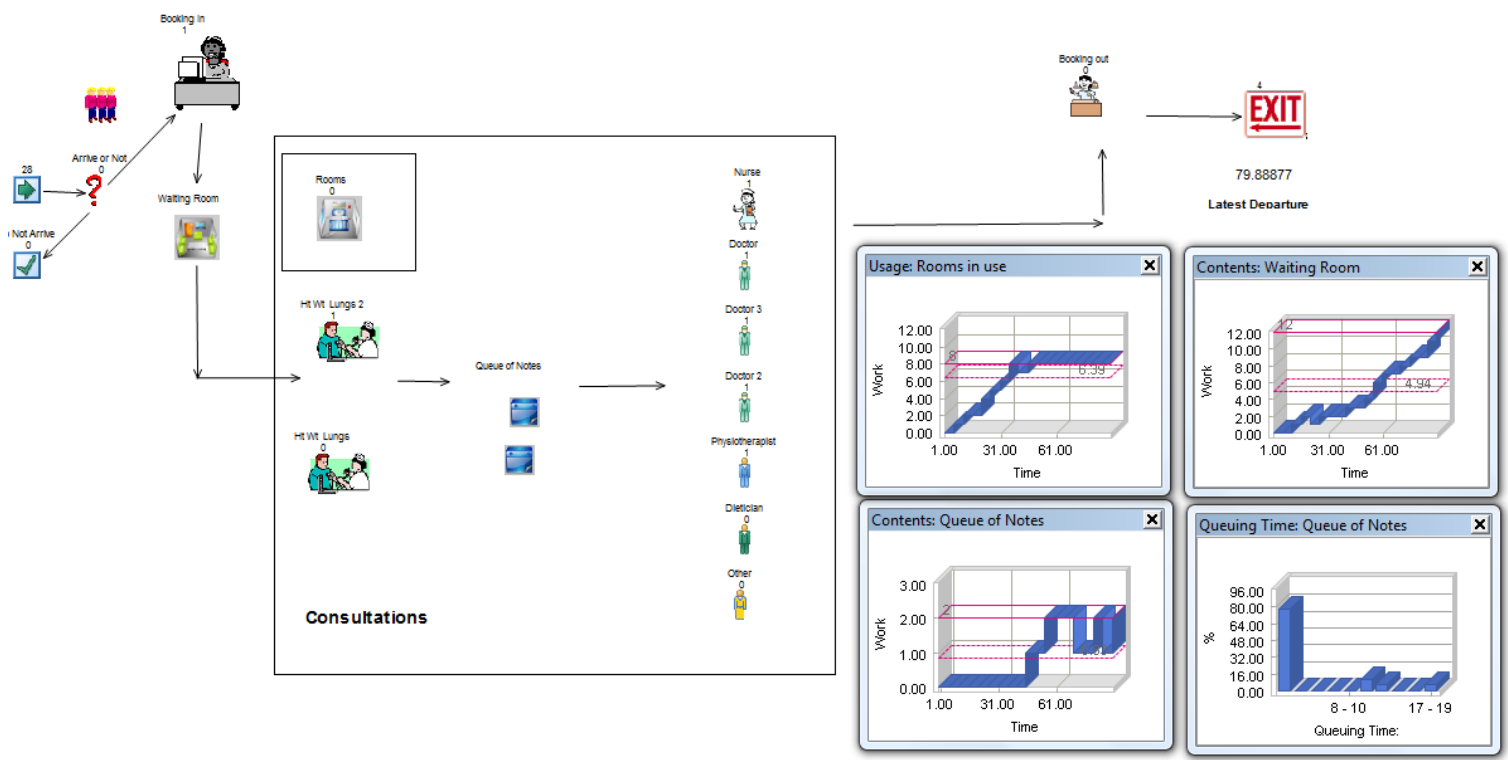

\section{Discussion and Conclusion}

DES and lean have a similar motivation - improvement of processes and service delivery. From a theoretical and empirical perspective we have demonstrated that they can be complementary methodologies. They are, however, largely adopted in isolation to one another. The SimLean approach aims to provide a fusion between DES and lean so they can work in mutual benefit. Indeed, SimLean represents a symbiotic relationship between DES and lean making the implementation of SimLean greater than the sum of DES and lean acting alone. The examples described above illustrate how SimLean Educate, Facilitate and Evaluate have provided successful implementations of DES with lean complementing each other in practice.

The key aim of SimLean is to improve the impact of both DES and lean enabling them to work in mutual benefit to the improvement of healthcare systems. From a simulation perspective, SimLean addresses the issue of stakeholder engagement with simulation, which is a critical problem with using DES in healthcare (Brailsford et al, 2009b). It does so in three ways. First, a lean event already calls upon multiple stakeholders at all levels of the healthcare organisation. By drawing DES into this environment it greatly increases the likelihood that the stakeholders will engage with the DES model. Second, using DES during a lean event provides a means for debating alternative views and providing an evidence base for reaching an accommodation of ideas. As a result, SimLean helps manage the conflicting 
interests of multiple stakeholders. Thirdly, because SimLean Educate involves the use of existing models and SimLean Facilitate involves rapid modelling, this mitigates the impediment of DES modelling taking too long for stakeholders to be engaged. Indeed, we have found that the use of DES during lean workshops has increased stakeholder interest in going on to full scale DES modelling, that is, SimLean Evaluate.

From a lean perspective, SimLean aims to improve the impact of lean in a healthcare environment. SimLean Educate enhances learning about lean through the use of pre-built standard simulation models. In particular, the simulation brings to life lessons about process flow in healthcare and helps to be a 'myth buster' regarding the beliefs held regarding the system. In this way it acts as a catalyst to change the focus of the discussion within the lean event. From a simulation perspective SimLean Educate means that the simulation intervention is carried out in a very short timeframe and so it allows engagement with simulation from a wider group of stakeholder.

SimLean Facilitate increases the impact of lean. For example, in healthcare lean focuses on the redesign of processes to reduce waste. However, our early research identified a key barrier to the implementation of a redesign was changing mindsets, not least because making changes to a process in a healthcare environment is not something that can be done easily, without disruption or without risk. As such, large impact changes in healthcare require a clear justification and rationale which need to be communicated clearly across all staff from the ward clerks to the Chief Executive. DES provides a means for doing this by allowing staff at all levels to better understand their process and to experiment with process changes in a computer simulated world which means the trialling is 'cheaper' and 'safer' than implementing physical changes.

SimLean Evaluate provides for a longer term fusion of simulation and lean, maintaining its impact and potentially improving the sustainability of lean. Overall SimLean generates a virtuous circle between DES and lean. Lean generates greater engagement with DES which in turn increases the impact of lean.

In summary, the research and examples given, show that SimLean makes simulation more accessible and lean more sustainable. It represents a new and innovative use of simulation which is rapid and makes lean process mapping in particular more dynamic. Future work on SimLean will involve further testing and refining of SimLean Educate and SimLean Facilitate. A number of SimLean Educate models could be developed for different contexts that could then be used by lean transformation teams during lean workshops. Tools could be provided that will help with the rapid development of SimLean Facilitate models, for instance, spreadsheets for handling data and tools for automatically generating simulation models from process maps. A web based handbook, that will enable lean practitioners to implement SimLean, is in the process of being developed. We also envisage trialling the concept in other contexts beyond healthcare. We believe that healthcare has been a useful context to develop SimLean due to some of the inherent challenges around time and the clinical/managerial divide. But we also believe that SimLean is not an approach that is suited 
to just this context. Implementing SimLean in contexts beyond healthcare will provide further evidence of the complementary roles of DES and lean.

\section{Acknowledgements}

The financial support of the Strategic Lean Implementation Methodology (SLIM) project (www2.warwick.ac.uk/fac/soc/wbs/projects/slim) is acknowledged. SLIM is funded by the Warwick Innovative Manufacturing Research Centre.

We are grateful for the advice and support of Matthew Cooke, Neil Davis and Ruth Davies, and for the time given by staff at University Hospitals Coventry and Warwickshire NHS Trust, Royal Bolton Hospital NHS Foundation Trust and Heart of England NHS Foundation Trust.

\section{References}

Aaby, K., Herrmann, J.W., Jordan, C.S., Treadwell, M. and Wood, K. (2006). Montgomery County's Public Health Service uses Operations Research to Plan Emergency Mass Dispensing and Vaccination Clinics. Interfaces, 36 (6), pp. 569-579.

Abdulmalek, F.A. and Rajgopal, J. (2006). Analyzing the Benefits of Lean Manufacturing and Value stream Mapping via Simulation: A Process Sector Case. International Journal of Production Economics, 107, pp. 223-236.

Anand, G. and Kodali, R. (2009). Simulation Model for the Design of Lean Manufacturing Systems - A Case Study. International Journal of Productivity and Quality Management, 4 (5-6), pp. 691-714.

Ashton, R., Hague, L., Brandreth, M., Worthington, D. and Cropper, S. (2005). A Simulation-Based Study of a NHS Walk-In Centre. Journal of the Operational Research Society, 56 (2), pp. 153-161.

Badurdeen, F. Marksberry, P., Hall, A. and Gregory, B. (2010). Teaching Lean Manufacturing with Simulations and Games: A Survey of Future Directions. Simulation \& Gaming, 41(4) 465-486.

Banks, J., Carson, J.S., Nelson, B.L. and Nicol, D.M. (2005). Discrete-Event System Simulation, $4^{\text {th }}$ ed. Prentice Hall, Upper Saddle River, NJ.

Bicheno, J. and Holweg, M. (2009). The Lean Toolbox, 4th ed. PICSIE Books, Buckingham, UK.

Brailsford, S.C. (2005). Overcoming the Barriers to Implementation of Operations Research Simulation Models in Healthcare. Clinical and Investigative Medicine, 28, pp. 312-315. 
Brailsford, S.C., Harper, P.R., Patel, B. and Pitt, M. (2009a). An Analysis of the Academic Literature on Simulation and Modelling in Health Care. Journal of Simulation, 3 (3), pp. 130140.

Brailsford, S.C., Bolt, T., Connell, C., Klein, J.H. and Patel, B. (2009b). Stakeholder Engagement in Health Care Simulation. Proceedings of the 2009 Winter Simulation Conference (M.D. Rossetti, R.R. Hill, B. Johansson, A. Dunkin, and R.G. Ingalls, eds.), IEEE, Piscataway, NJ, pp. 1840-1849.

Brailsford, S. and Vissers, J. (2011). OR in Healthcare: A European Perspective. European Journal of Operational Research, 212, pp. 223-234.

Brandao de Souza, L. (2009). Trends and Approaches in Lean Healthcare, Leadership in Health Services 22 (2), pp. 121-139.

Chang, S.-J., Hsiao, H.-C., Huang, L.-H. and Chang, H. (2011). Taiwan Quality Indicator Project and Hospital Productivity Growth. Omega, 39 (1), pp. 14-22.

Dennis, S., King, B., Hind, M. and Robinson, S. (2000). Applications of Business Process Simulation and Lean Techniques in British Telecommunications Plc. Proceedings of the 2000 Winter Simulation Conference (J.A. Joines, R.R. Barton, K. Kang, and P.A. Fishwick, eds.). IEEE, Piscataway, NJ, pp. 2015-2021.

Detty, R.B. and Yingling, J.C. (2000). Quantifying Benefits of Conversion to Lean Manufacturing with Discrete Event Simulation: A Case Study. International Journal of Production Research, 38 (2), pp. 429-445.

Eldabi, T. (2009). Implementation Issues of Modeling and Healthcare Problems: Misconceptions and Lessons. Proceedings of the 2009 Winter Simulation Conference (M.D. Rossetti, R.R. Hill, B. Johansson, A. Dunkin, and R.G. Ingalls, eds.), IEEE, Piscataway, NJ, pp. 1831-1839.

Eldabi, T., Paul, R.J. and Young, T. (2007). Simulation Modelling in Healthcare: Reviewing Legacies and Investigating Futures. Journal of the Operational Research Society, 58 (2), pp. 262-270.

Fone, D., Hollinghurst, S., Temple, M., Round, A., Lester, N., Weightman, A., Roberts, K., Coyle, E., Bevan, G. and Palmer, S. (2003). Systematic Review of the Use and Value of Computer Simulation Modelling in Population Health and Health Care Delivery. Journal of Public Health Medicine, 25 (4), pp. 325-335.

Fredendall, L.D., Ojha, D. and Patterson, J.W. (2010). Concerning the Theory of Workload Control. European Journal of Operational Research, 201, pp. 99-111. 
Fujimoto, T. (1999). Organisational for Effective Product Development - The Case of the Global Automobile Industry. Boston, Harvard University Graduate School of Business Administration.

Griffiths, J.D., Jones, M., Read, M.S. and Williams, J.E. (2010). A Simulation Model of BedOccupancy in a Critical Care Unit. Journal of Simulation, 4 (1), pp. 52-59.

Günal M.M. and Pidd, M. (2010) Discrete Event Simulation for Performance Modelling in Health Care: A Review of the Literature. Journal of Simulation, 4 (1), pp. 42-51.

Günal M.M. and Pidd, M. (2011) DGHPSIM: Generic Simulation of Hospital Performance. ACM Transactions on Modeling and Computer Simulation (TOMACS). 21 (4), forthcoming.

Guthrie, J. (2006). The Joys of a Health Service Driven by Toyota. Financial Times.

Hagtvedt, R., Griffin, P., Keskinocak, P. and Roberts, R. (2009). A Simulation Model to Compare Strategies for the Reduction of Health-Care-Associated Infections. Interfaces, 39 (3), pp. 256-270.

Hines, P., Holweg, M. and Rich, N. (2004). Learning to Evolve. A Review of Contemporary Lean Thinking, International Journal of Operations and Production Management 24(10), pp. 994-1011.

Hines, P., Found, P. and Harrison, R. (2008). Staying Lean: Thriving, Not Just Surviving. Cardiff, Lean Enterprise Research Centre, Cardiff University, Cardiff.

Hollocks, B. (1992). A Well-kept Secret? Simulation in Manufacturing Industry Reviewed. OR Insight, 5 (4), pp. 12-17.

Hollocks, B. (2006). Forty Years of Discrete-Event Simulation - A Personal Reflection. Journal of the Operational Research Society, 57 (12), pp. 1383-1399.

Hollocks, B. (2008). Intelligence, Innovation and Integrity - KD Tocher and the Dawn of Simulation. Journal of Simulation, 2 (3), pp. 128-137.

Holweg, M. (2007). The Genealogy of Lean Production, Journal of Operations Management 25, pp. 420-437.

Jacobson, S.H., Hall, S.N. and Swisher, J.R. (2006). Discrete-Event Simulation of Health Care System. Patient Flow: Reducing Delay in Healthcare Delivery (R.W. Hall, ed.), Springer International Series, pp. 211-252.

Jahangirian, M., Eldabi, T., Naseer, A., Stergioulas, L.K. and Young, T. (2010). Simulation in Manufacturing and Business: A Review. European Journal of Operational Research, 203, pp. 1-13. 
Jun, J.B., Jacobson, S.H. and Swisher, J.R. (1999). Application of Discrete-Event Simulation in Health Care Clinics: A Survey. Journal of the Operational Research Society, 50 (2), pp. 109-123.

Katsaliaki, K. And Brailsford, S.C. (2007). Using Simulation to Improve the Blood Supply Chain. Journal of the Operational Research Society, 58 (2), pp. 219-227.

Khurma, N., Bacioiu, G.M. and Pasek, Z.J. (2008). Simulation-Based Verification of Lean Improvement for Emergency Room Process. Proceedings of the 2008 Winter Simulation Conference (S. J. Mason, R. R. Hill, L. Mönch, O. Rose, T. Jefferson, J. W. Fowler, eds.), IEEE, Piscataway, NJ, pp. 1490-1499.

Kuljis, J., Paul, R.J. and Stergioulas, L.K. (2007). Can Health Care Benefit from Modeling and Simulation Methods in the Same Way as Business and Manufacturing Has? Proceedings of the 2007 Winter Simulation Conference (Henderson, S.G., Biller, G., Hsieh, M.-H., Shortle, J., Tew, J.D., Barton, R.R., eds.), IEEE, Piscataway, NJ, pp. 1449-1453.

Marvel J.H. and Standridge, C.R. (2009). A Simulation-Enhanced Lean Design Process. Journal of Industrial Engineering and Management, 2 (1), pp. 90-113.

Mustafee, N., Katsaliaki, K. and Taylor, S.J.E. (2010). Profiling Literature in Healthcare Simulation. Simulation, 86 (8-9), pp. 543-558.

Nance, R.E. and Sargent, R.G. (2002). Perspectives on the Evolution of Simulation. Operations Research 50 (1), pp. 161-172.

Ncube, L.B. (2010). A Simulation of Lean Manufacturing: The Lean Lemonade Tycoon 2. Simulation \& Gaming, 41(4), pp. 568-586.

NHSI (2007). Going Lean in the NHS. http://www.institute.nhs.uk/option,com_joomcart/Itemid,26/main_page,document_product_in fo/products_id,231.html (Accessed January 2011).

NHSI (2010a). Quality and Service Improvement Tools: Modelling and Simulation. www.institute.nhs.uk/quality_and_service_improvement_tools/quality and service_improve ment_tools/modelling_and_simulation.html (Accessed January 2011).

NHSI (2010b). Lean Thinking. http://www.institute.nhs.uk/quality_and_value/lean_thinking/lean_thinking.html (Accessed January 2011).

NVivo (2010). www.qsrinternational.com/products_nvivo.aspx (Accessed January 2011).

Ohno, T. (1988). The Toyota Production System: Beyond Large-Scale Production. Productivity Press, Portland. 
Paul, S.A., Reddy, M.C. and DeFlitch, C.J. (2010). A Systematic Review of Simulation Studies Investigating Emergency Department Overcrowding. Simulation, 86 (8-9), pp. 559571.

Pidd, M. (2004). Computer Simulation in Management Science, $5^{\text {th }}$ ed. Wiley, Chichester, UK.

Pitt, M. (2008). Simulation for Strategic Planning in Health Care - 'The State of the Art.' Briefing Report for the Institute: www.institute.nhs.uk/images//documents/BuildingCapability/ScenarioGenerator/state-of-theart.pdf (Accessed February 2011).

Proudlove, N.C., Black, S. and Fletcher, A. (2007). OR and the Challenge to Improve the NHS: Modelling for Insight and Improvement in in-Patient Flows. Journal of the Operational Research Society, 58, pp. 145-158.

Radnor, Z.J., Walley, P., Stephens, A. and Bucci, G. (2006). Evaluation of the Lean Approach to Business Management and its use in the Public Sector, Government Social Research.

Radnor, Z.J. and Boaden, R. (2008). Lean in Public Services - Panacea or Paradox?, Public Money and Management, 28 (1), pp. 3-7.

Radnor, Z.J., Davies, R. and Burgess, N. (2009). How much Lean are English Hospitals Implementing? National Health Executive, pp. 60-62.

Radnor, Z.J. (2010). Review of Business Process Improvement Methodologies in Public Services. Advanced Instuite of Management, London.

Radnor, Z.J. and Holweg, M., (2010). From Tools to Systems: A Critical Appraisal of Lean Healthcare Implementations. European Operations Management Association Conference. Sousa R. Porto.

Reijersa, H.A. and Liman Mansar, S. (2005). Best Practices in Business Process Redesign: An Overview and Qualitative Evaluation of Successful Redesign Heuristics. Omega, 33 (4), pp. 283-306.

Robinson, S. (2004). Simulation: The Practice of Model Development and Use. Wiley, Chichester, UK.

Robinson, S. (2005). Discrete-Event Simulation: From the Pioneers to the Present, What Next? Journal of the Operational Research Society, 56 (6), pp. 619-629.

Robinson, S. (2008). Conceptual Modelling for Simulation Part I: Definition and Requirements. Journal of the Operational Research Society, 59 (3), pp. 278-290. 
Shannon, P.W., Krumwide, K.R. and Street, J.N. (2010). Using Simulation to Explore Lean Manufacturing Implementation Strategies. Journal of Management Education, 34 (2), pp. 280-302.

Silvester, K., Lendon, R., Bevan, H.R.S. and Walley, P. (2004). Reducing Waiting Times in the NHS: Is Lack of Capacity the Problem?, Clinician in Management, 12 (3), pp. 105-111.

SIMUL8 (2010). www.simul8.com (Accessed January 2011).

Solding, P. and Gullander, P. (2009). Concepts for Simulation Based Value Stream Mapping. Proceedings of the 2009 Winter Simulation Conference (M.D. Rossetti, R.R. Hill, B. Johansson, A. Dunkin, and R.G. Ingalls, eds.), IEEE, Piscataway, NJ, pp. 2231-2237.

Spear, S. (2005). Fixing Health Care from the Inside, Harvard Business Review(September), pp. 78-91.

Tocher, K.D. and Owen, D.G. (2008). The Automatic Programming of Simulations. Journal of Simulation, 2 (3), pp. 143-152.

Womack, J.P., Jones, D.T. and Roos, D. (1990). The Machine That Changed the World. Rawson Associates, New York.

Womack, J.P. and Jones, D.T. (1996). Lean Thinking, Book Review in Financial Times, 30th September 1996

Worthington, C., Robinson, S., Burgess, N. and Radnor, Z. (2010). Rapid Modelling of Patient Flow in a Health Care Setting: Integrating Simulation with Lean. Rapid Modelling and Quick Response: Intersection of Theory and Practice (Reiner, G., ed.). Springer, London, pp. 131-142.

Wysocki, B. (2004). How Toyota's Production Techniques are Applied to Hospitals, Wall Sreet Journal

Young, T., Brailsford, S., Connell, C., Davies, R., Harper, P. and Klein, J.H. (2004). Using Industrial Processes to Improve Patient Care. British Medical Journal, 328, pp. 162-164.

Young, T.P. and McClean, S.I. (2008). A Critical Look at Lean Thinking in Healthcare, Quality \& Safety in Health Care, 17, pp. 382-286.

Young, T., Eatock, J., Jahangirian, M., Naseer, A. and Lilford, R. (2009). Three Critical Challenges for Modelling and Simulation in Healthcare. Proceedings of the 2009 Winter Simulation Conference (M.D. Rossetti, R.R. Hill, B. Johansson, A. Dunkin, and R.G. Ingalls, eds.), IEEE, Piscataway, NJ, pp. 1823-1830. 
